\title{
Bacterial Blight of Broccoli Raab: A New Disease Caused by a Pathovar of Pseudomonas syringae
}

\author{
Steven T. Koike and Diana M. Henderson, University of California Cooperative Extension, Salinas 93901; \\ Hamid R. Azad and Donald A. Cooksey, Department of Plant Pathology, University of California, Riverside \\ 92521; and E. L. Little, Department of Crop and Soil Sciences, University of Georgia, Athens 90602
}

\begin{abstract}
Koike, S. T., Henderson, D. M., Azad, H. R., Cooksey, D. A., and Little, E. L. 1998. Bacterial blight of broccoli raab: A new disease caused by a pathovar of Pseudomonas syringae. Plant Dis. 82:727-731.

Bacterial blight is a new disease of broccoli raab or rappini (Brassica rapa subsp. rapa) that has developed on commercially grown crops in the Salinas Valley (Monterey County) in California. Symptoms consist of small, angular, water-soaked flecks on lower foliage that are visible from both adaxial and abaxial sides of the leaves. These flecks expand and become surrounded by bright yellow borders. With time, multiple leaf spots coalesce and result in large, irregular necrotic areas, extensive leaf yellowing, and eventual leaf death. If symptoms develop on the uppermost leaves attached to the inflorescence, the shoot loses market quality and will not be harvested. Pseudomonas syringae was consistently isolated from symptomatic plants, and selected strains caused similar symptoms when inoculated onto broccoli raab test plants. Broccoli raab strains caused leaf spot symptoms on nine other Cruciferous plants, as well as on three grass species (California brome, oat, and common timothy). Conversely, broccoli raab was not infected by $P$. syringae pathovars coronafaciens, maculicola, and tomato. Broccoli raab strains were positive for coronatine toxin production. Fatty acid analyses indicated that the $P$. syringae from broccoli raab was most closely related to $P$. syringae pvs. coronafaciens and maculicola, but its distinct host range suggests that it may be considered a separate pathovar.
\end{abstract}

Broccoli raab (Brassica rapa subsp. rapa), also known as rappini or broccoletto di rapa, is a leafy vegetable that is widely grown in Europe (5) and has in recent years become an important crop in coastal California. The central, immature inflorescences along with attached lateral shoots and leaves are harvested, boxed, and shipped to markets primarily in the eastern part of the United States. During the past 3 years in the Salinas Valley (located in Monterey County, California), a previously undescribed foliar disease occurred on the crop.

Initial symptoms on plants in the field consist of small (2 to $4 \mathrm{~mm}$ diameter), angular, water-soaked flecks on lower foliage that are visible from both adaxial and abaxial sides of the leaves (Fig. 1). These flecks expand and become surrounded by bright yellow borders. As the disease progresses, multiple leaf spots coalesce and

Corresponding author: S. T. Koike

E-mail: stkoike@ucdavis.edu

Accepted for publication 31 March 1998.

Publication no. D-1998-0507-01R

(C) 1998 The American Phytopathological Society result in large, irregular necrotic areas and extensive leaf yellowing. Affected leaf tissue later dries, turns tan, and becomes papery in texture. Disease progresses upward from these lower leaves to leaves higher in the plant canopy. If symptoms develop on the uppermost leaves attached to the inflorescence, the shoot loses market quality and will not be harvested. Under conditions favorable for disease development, leaf infections can be extensive and cause significant reduction in plant growth. When sections of leaf lesions were cut, mounted in water, and examined with phase-contrast microscopy, bacterial streaming was consistently observed. The purpose of this study was to determine and ease.

\section{MATERIALS AND METHODS}

Isolation of the causal agent. Symptomatic leaves were surface-sterilized ( $0.525 \%$ sodium hypochlorite; $1 \mathrm{~min})$, and small $(3 \times 3 \mathrm{~mm})$ sections of tissue were aseptically excised from leaf spot margins and macerated in $40 \mu \mathrm{l}$ each of sterile distilled water. The resulting suspensions were streaked onto sucrose peptone agar (SPA) plates and incubated at $24^{\circ} \mathrm{C}$. After 3 to 5 days, representative bacterial strains characterize the causal agent of this dis- were purified by restreaking single colonies onto SPA and then kept in $40 \%$ glycerol at $-70^{\circ} \mathrm{C}$ for routine use or lyophilized for long-term storage. To test for possible fungal pathogens, small leaf sections were aseptically removed and placed onto acidified potato dextrose agar $(2 \mathrm{ml}$ of lactic acid per liter). Plates were incubated under lights at $24^{\circ} \mathrm{C}$ and examined after 3 to 7 days for fungal growth.

Characterization of the bacteria. Five isolated strains of recovered bacteria were tested for morphological, biochemical, and physiological characteristics. Morphology was determined by examining strains grown on mannitol-glutamate-yeast extract (MGY) agar plates (7). Gram and flagellar stains were performed as described by Schaad (15). The following tests were conducted: levan formation and the ability to induce potato rot (12), catalase and oxidase reactions (11), arginine dihydrolase (18), ability to induce pitting on polypectate gel (3), and hypersensitive reaction on tobacco leaves (8). Nitrate reduction, urease activity, gelatine liquefaction, and utilization of sugars, sugar alcohols, and organic acids as sole carbon sources were determined using methods of Schaad (15). Growth on MacConkey agar was determined by streaking bacteria on MacConkey agar plates (Difco Laboratories, Detroit, MI) and incubating them at $28^{\circ} \mathrm{C}$ for 7 days.

For fatty acid analyses, strains were cultured on trypticase soy broth agar at $28^{\circ} \mathrm{C}$ for 24 to $48 \mathrm{~h}$, then extracted for fatty acid methyl esters using a standard method (16). Fatty acids were analyzed with the Sherlock Microbial Identification System Version 2.11 (MIDI Inc., Newark, DE) that used an automated GC 6890 HewlettPackard gas chromatograph fitted with a $25 \times 0.2 \mathrm{~mm}$ phenyl methyl silicone-fused silica capillary column, an HP 7673 automatic sampler, and HP Chem Station Software (16). The analyses included assessing the degree of similarity of fatty acid composition. Analyses were conducted three times.

Strains were also compared three times by their carbon source utilization profiles on Biolog GN microplates (Biolog, Inc., Hayward, CA). In addition to the broccoli 
raab strains, the following $P$ syringae strains were included in all tests as controls: P. syringae pv. coronafaciens 089349 (NCPPB600), P. syringae pv. maculicola 0197-29 and 0197-30, P. syringae pv. syringae 0584-6 from Prunus species, and P. syringae pv. tomato $0683-23$.

Analysis of toxin production. Broccoli raab strains 1097-11 and 1097-12 were grown in $10 \mathrm{ml}$ of HSC medium (1) on a rotary shaker for 7 days at $18^{\circ} \mathrm{C}$. The toxins were prepared as described by Palmer and Bender (14) and fractionated by a high-performance liquid chromatograph (HPLC). The HPLC column was a $0.46 \times$ $25 \mathrm{~cm} \mu$ Bandapak C18, $5 \mu \mathrm{m}$. Mobile phase was $31 \%$ acetonitrile/0.5\% TFA/ water. Three fractions were collected, and $3 \mu \mathrm{l}$ of each fraction was applied to needleprick wounds on 3-week-old tomato plants.
The development of chlorotic symptoms was recorded after 3 to 7 days. $P$. syringae pv. glycinea (0385-2), P. syringae pv. syringae (0584-6), P. syringae pv. coronafaciens (0893-49), and P. syringae pv. tomato (0683-23) were included as controls.

Pathogenicity of broccoli raab strains on broccoli raab and other crucifers. To test pathogenicity on the plant of origin, inocula of four randomly selected representative strains (1097-11, 1097-12, 1097$13,1097-14)$ were prepared by growing nutrient broth (Difco, $8 \mathrm{~g} /$ liter) shake cultures for $48 \mathrm{~h}$. Tween $20(0.05 \%)$ was added to the resulting bacterial suspensions (containing $10^{7} \mathrm{CFU} / \mathrm{ml}$ as determined by dilution plating), and each suspension was sprayed until runoff using a hand mister onto 18 one-month-old broccoli raab plants (cv. Spring). Control broccoli raab plants were treated with sterile nutrient broth plus Tween 20. Plants were placed in a humid chamber for $48 \mathrm{~h}$ and then maintained in a greenhouse at 20 to $24^{\circ} \mathrm{C}$. Tests were conducted three times.

Because of the extensive crucifer plantings in the Salinas Valley, in another experiment the same four strains were prepared as described above and inoculated onto 12 one-month-old plants of each of the following: arugula (Eruca sativa), bok choy (Brassica campestris subsp. chinensis cv. Joi Choi), broccoli (Brassica oleracea subsp. botrytis cv. Greenbelt), cabbage (Brassica oleracea subsp. capitata cv. Grenedere), cauliflower (Brassica oleracea subsp. botrytis cv. White Rock), Chinese cabbage (Brassica campestris subsp. pekinensis cv. Cha-Cha), Japanese mustard (Brassica campestris subsp. nipposinica
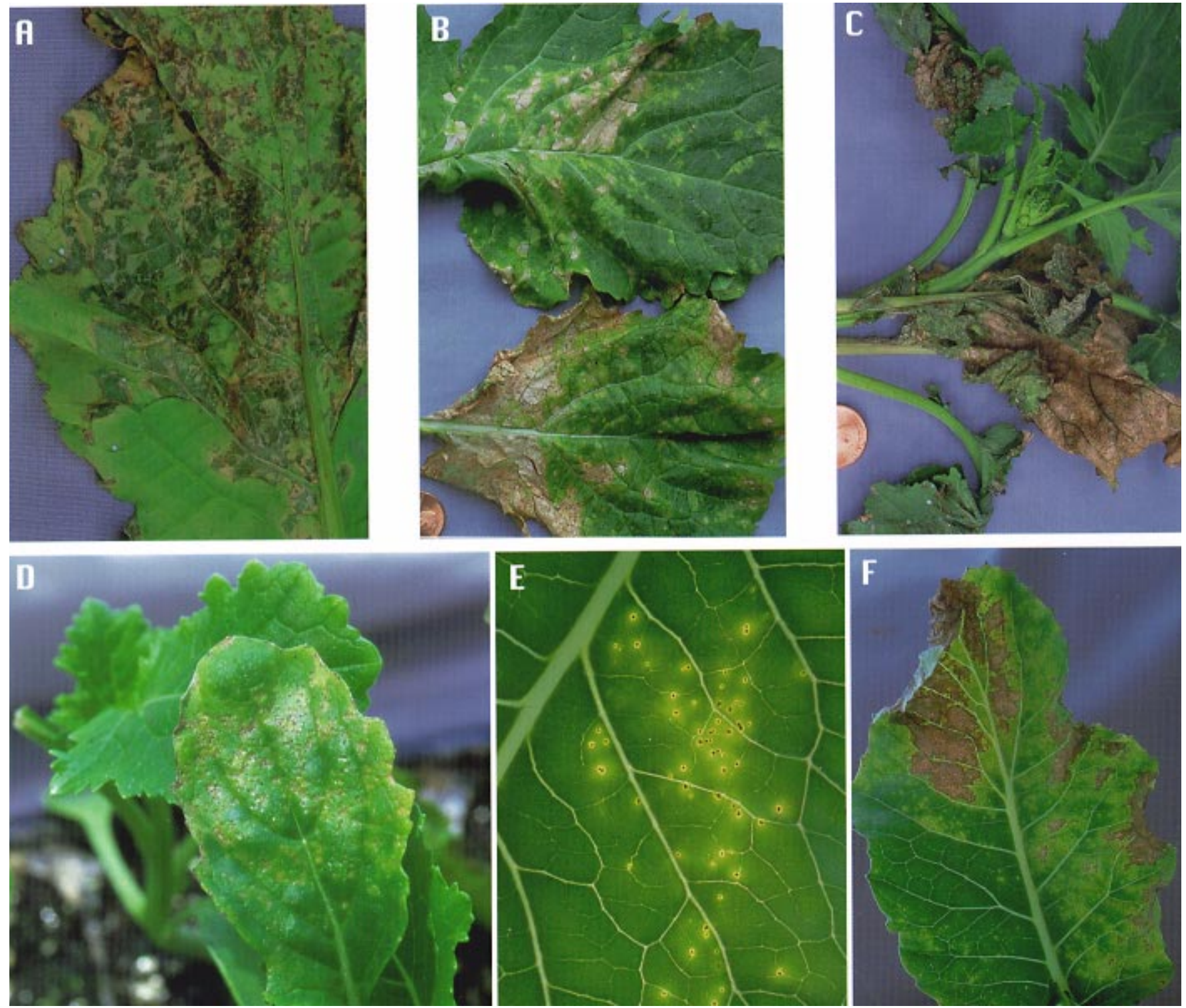

Fig. 1. Symptoms of bacterial blight of broccoli raab caused by a pathovar of Pseudomonas syringae. (A) Angular, water-soaked spots of naturally infected broccoli raab in the early stages of disease development. (B) Dried, tan leaf spots of naturally infected broccoli raab in later stages of disease development. (C) Death of leaf in advanced stages of naturally infected broccoli raab, causing the shoot to be unmarketable. (D) Necrotic spots and chlorosis of an inoculated broccoli raab seedling. (E) Early stage necrotic spots and chlorotic borders caused by a broccoli raab strain inoculated onto cauliflower. (F) Late-stage symptoms of extensive necrosis and chlorosis caused by a broccoli raab strain inoculated onto cauliflower. 
cv. Mizuna), red mustard (Brassica juncea subsp. rugosa cv. Red Giant), and tah tsai (Brassica campestris subsp. narinosa cv. Tokita). For a positive control, broccoli raab (cv. Spring) was inoculated along with the other test plants. Negative control plants of all cultivars were treated with sterile nutrient broth plus Tween 20. Plants were subsequently incubated as described previously and evaluated for symptom severity after 7, 14, and 28 days. Plant response was rated according to the following scale: $-=$ no symptoms, $+=$ small water-soaked lesions only, $++=$ limited necrotic lesions and some chlorosis, $+++=$ extensive necrotic lesions and chlorosis. The experiment was conducted twice.

Pathogenicity of broccoli raab strains on other $P$. syringae hosts. Because preliminary information suggested that the broccoli raab pathogen may be closely related to $P$. syringae $\mathrm{pv}$. coronafaciens, a pathogen of grass species, or $P$. syringae pv. maculicola, the causal agent of bacterial leaf spot of crucifers, the same four broccoli raab strains were prepared as described previously and inoculated onto 12 one-month-old plants of each of the following: California brome (Bromus carinatus), corn (Zea mays cvs. Kandy Korn and Silver Queen), oat (Avena sativa cv. Montezuma), rye (Secale cereale cv. Merced), common timothy (Phleum pratense), cauliflower (cv. White Rock), tomato (Lycopersicon esculentum cv. Early Girl), and broccoli raab (cv. Spring). Tomato was included because of the reported relatedness of $P$. syringae pv. maculicola to $P$. syringae pv. tomato $(13,19)$. Control plants were treated with sterile nutrient broth plus Tween 20. Plants were subsequently incubated as described above, and the experiment was conducted twice.

Pathogenicity of other $P$. syringae pathovars on broccoli raab. Nutrient broth inocula for one $P$. syringae pv. coronafaciens strain (0893-49 [NCPPB 600], isolated from oat), four $P$. syringae pv. maculicola strains (0197-30, 0694-18, 0788-18, 0197-29), three $P$. syringae pv. tomato strains (0482-1, 0183-4, 0783-23), and four broccoli raab strains (1097-11, 1097-12, 1097-13, 1097-14) were prepared as described previously and spray inoculated onto 18 one-month-old broccoli raab plants (cv. Spring) using the same method as previously described. The $P$. syringae pv. maculicola, $P$. syringae pv. tomato, and broccoli raab strains were also inoculated onto the cauliflower, tomato, and grass hosts listed previously. Plants were incubated as previously described, and the experiment was conducted twice.

\section{RESULTS}

Isolation and characterization of the causal agent. Although some foliar fungal pathogens have recently been documented on broccoli raab crops in the Salinas Valley
$(9,10)$, no such organisms were observed on or recovered from the leaf sections placed onto acidified potato dextrose agar plates. However, a bacterium was consistently isolated from symptomatic broccoli circular, entire, and convex. Five representative strains glistened on MGY plates and fluoresced with a bluish green pigment. All strains were gram negative and had one to five polar flagella. In LOPAT tests, strains were positive for levan production and tobacco hypersensitivity, but negative for oxidase, arginine dihydrolase, and ability to rot potato (Table 1), identifying the organisms as $P$. syringae. Strains did not reduce nitrate nor liquefy gelatine and were variable for urease activity (Table 1). Mannitol, inositol, sorbitol, glycerol, raab leaves and formed colonies that were

glucose, sucrose, arabinose, mannose, D (-) tartrate, citrate, succinate, malonate, L (-), L (+), and DL-tartrate, and DL-lactate were utilized as carbon sources. Strains were not able to utilize erythritol, D (+) tartrate, meso-tartrate, molybdate, acetate, propionate, maleate, rhamnose, and $\mathrm{L}(+)$ lactate. Utilization of $\mathrm{L}(-)$ lactate and growth on MacConkey agar were weakly positive. None of the isolates induced pitting on polypectate gel.

Colonies formed by the four other $P$. syringae pathovars used as controls were also entire, circular, and convex on MGY plates, but were not glistening. Reactions to their biochemical and physiological tests are shown in Table 1.

In cellular fatty acid analyses, the broccoli raab strains were closely related to $P$.

Table 1. Biochemical and physiological characteristics of broccoli raab strains compared with four Pseudomonas syringae pathovars

\begin{tabular}{|c|c|c|c|c|c|}
\hline \multirow[b]{2}{*}{ Characteristics $^{\mathbf{y}}$} & \multirow{2}{*}{$\begin{array}{c}\text { Broccoli } \\
\text { raab strains }\end{array}$} & \multicolumn{4}{|c|}{ Pseudomonas syringae pathovars ${ }^{\mathrm{z}}$} \\
\hline & & coronafaciens & maculicola & syringae & tomato \\
\hline Number tested & 5 & 1 & 2 & 1 & 1 \\
\hline Fluorescent & + & + & + & + & + \\
\hline Gram negative & + & + & + & + & + \\
\hline 1 to 5 polar flagella & + & + & + & + & + \\
\hline Levan production & + & + & + & + & + \\
\hline Oxidase activity & - & - & - & - & - \\
\hline Potato rot ability & - & - & - & - & - \\
\hline Arginine dihydrolase & - & - & - & - & - \\
\hline Tobacco hypersensitivity & + & + & + & + & + \\
\hline Polypectate gel pitting & - & - & - & - & - \\
\hline Nitrate reduction & - & - & - & - & - \\
\hline Urease activity & $+/-$ & - & - & + & - \\
\hline Liquefy gelatine & - & - & - & - & + \\
\hline \multicolumn{6}{|l|}{ Carbon source utilization } \\
\hline $\mathrm{D}(-)$ tartrate & + & - & + & - & + \\
\hline Meso-tartrate & - & + & + & + & + \\
\hline $\mathrm{L}(-)$ lactate & w & w & w & + & w \\
\hline Erythritol & - & - & - & + & - \\
\hline Mannitol & + & + & + & + & w \\
\hline Sorbitol & + & + & $\mathrm{w}$ & + & + \\
\hline MacConkey agar & $\mathrm{w}$ & w & w & w & w \\
\hline
\end{tabular}

y Reactions were evaluated as follows: $+=$ positive reaction; $-=$ negative reaction; $+/-=$ variable reaction; $\mathrm{w}=$ weak reaction after 7 days at $28^{\circ} \mathrm{C}$.

${ }^{\mathrm{z}}$ P. syringae pathovars were the following: pv. coronafaciens (0893-49) from oat, pv. maculicola (0197-29 and 0197-30) from crucifers, pv. syringae (0584-6) from Prunus spp., and pv. tomato (0683-23) from tomato.

Table 2. Severity of symptoms of crucifers inoculated with broccoli raab strains and evaluated at 7 , 14 , and 28 days

\begin{tabular}{lccc}
\hline & & Symptom severity $^{\mathbf{z}}$ & \\
\cline { 2 - 4 } Crucifer host & $\mathbf{7}$ days & $\mathbf{1 4}$ days & $\mathbf{2 8}$ days \\
\hline Broccoli raab & + & ++ & +++ \\
Arugula & - & + & + \\
Bok choy & + & ++ & +++ \\
Broccoli & + & + & ++ \\
Cabbage & + & + & ++ \\
Cauliflower & + & ++ & +++ \\
Chinese cabbage & + & ++ & +++ \\
Japanese mustard & - & + & + \\
Red mustard & - & ++ & ++ \\
Tah tsai & + & ++ & +++ \\
Negative controls & - & - & - \\
(all cultivars) & & &
\end{tabular}

${ }_{\mathrm{z}}$ Plants were evaluated 7, 14, and 28 days after inoculation and rated using the following scale: $-=$ no symptoms, $+=$ small water-soaked lesions only, $++=$ limited necrotic lesions and some chlorosis, $+++=$ extensive necrotic lesions and chlorosis. 
syringae pv. coronafaciens and $P$. syringae pv. maculicola. Percent similarities to these bacteria were 78.4 to 96.0 and 85.2 to 96.4 , respectively, depending on the isolate tested.

The Biolog data base placed the broccoli raab strains closest to $P$. syringae pv. hibi$s c i$, with similarity percentages ranging from 62.7 to $77.2 \%$. In this data base, the $P$. syringae pv. tomato strain was also identified as $P$. syringae pv. hibisci, indicating a close relatedness between broccoli raab and tomato pathogens.

Analysis of toxin production. Analysis of toxin extracts from broccoli raab strains, and from the positive control strains of $P$. syringae pv. glycinea, $P$. syringae pv. coronafaciens, and $P$. syringae pv. tomato, indicated that coronatine toxin was produced. HPLC analysis resulted in distinct peaks with retention times that were consistent with authentic coronatine (1), and the expected chlorosis developed on tomato leaves inoculated with fractions containing the coronatine peaks. Coronatine was not detected from the negative control strain of P. syringae pv. syringae.

Pathogenicity of broccoli raab strains on broccoli raab and other crucifers. When four representative broccoli raab strains were inoculated onto broccoli raab plants, water-soaked, chlorotic, and necrotic symptoms developed and were similar to those observed on diseased plants in the field. Bacteria morphologically similar to the original strains were consistently isolated from test plants, and after characterization were confirmed to be identical to the original strains. Results from the three experiments were the same.

All crucifers inoculated with broccoli raab strains developed symptoms, but symptoms varied among hosts (Table 2). Bok choy, cauliflower, Chinese cabbage, and tah tsai developed extensive watersoaking, chlorosis, and necrosis that were similar to symptoms on broccoli raab. Broccoli and cabbage developed extensive leaf flecking with water-soaked spots, but after 28 days had only slight chlorosis and necrosis. Red mustard developed extensive leaf flecking and chlorosis, but showed limited necrotic symptoms. Japanese mustard developed extensive leaf flecking only. For arugula, the only symptoms were minute, purple flecks that did not expand in size. Bacteria morphologically similar to the original strains were isolated from all crucifer hosts (including arugula), as well as from broccoli raab control plants. Reisolated strains were characterized and confirmed to be identical to the original strains. None of the control plants treated with sterile nutrient broth developed symptoms. Results from both experiments were the same.

Pathogenicity of broccoli raab strains on other $P$. syringae hosts. The broccoli raab strains caused leaf spot symptoms to develop on California brome, oat, common timothy, cauliflower, and control broccoli raab that initially consisted of water-soaked areas, followed by the development of chlorotic patches on the leaves (Table 3). Bacteria morphologically similar to the original strains were isolated from symptomatic leaves, characterized, and confirmed to be identical to the original strains. The two corn cultivars, rye, and tomato remained symptomless. None of the control plants treated with sterile nutrient broth developed symptoms. Results from both experiments were the same.

Pathogenicity of other $P$. syringae pathovars on broccoli raab. Broccoli raab failed to develop symptoms when spray inoculated with the one $P$. syringae pv. coronafaciens strain from oat, four $P$. syringae pv. maculicola strains, and three $P$. syringae pv. tomato strains. Positive control broccoli raab plants inoculated with broccoli raab strains developed typical leaf spot symptoms. The $P$. syringae pv. maculicola strains caused leaf spots to form on cauliflower (all four strains) and tomato (0197-30 and 0788-18 only). P. syringae pv. tomato caused leaf spot symptoms only on tomato (all three strains). None of the negative control plants treated with sterile nutrient broth developed symptoms. Results from both experiments were the same.

For the cauliflower plants that were inoculated with either $P$. syringae pv. maculicola or broccoli raab strains, developing symptoms were indistinguishable from each other. Initial symptoms of both pathogens consisted of small, angular, watersoaked flecks which were later surrounded by bright yellow chlorotic borders. As disease developed, flecks coalesced and necrosis resulted.

\section{DISCUSSION}

This appears to be the first report of a foliar bacterial disease of broccoli raab, named here as bacterial blight, caused by a $P$. syringae pathovar. Our morphological, biochemical, and physiological analyses indicate that the pathogen belongs to an interrelated group of pathovars that includes $P$. syringae pv. tomato, $P$. syringae pv. maculicola, $P$. syringae pv. coronafaciens, $P$. syringae pv. apii, and $P$. syringae pv. antirrhini $(6,12,19)$. The production of coronatine by broccoli raab strains is also consistent with their relatedness to certain members of this group which contain conserved DNA sequences, usually plasmidborne, involved in biosynthesis of the phytotoxin and the consequent ability to achieve high population numbers in planta $(1,2)$. Some studies have identified physiological and genetic similarities, overlapping host ranges, and have even suggested synonymy between some of the pathovars in this group $(6,13,17)$.

Other data suggest greater distinction between these pathovars, as well as subpathovar groupings $(4,6,19)$. Fatty acid analyses suggested that the broccoli raab strains were most closely related to $P$. $s y$ ringae pv. coronafaciens and $P$. syringae pv. maculicola, but pathogenicity studies indicated a distinct host range for the broccoli raab strains. Of the related pathovars tested, none were pathogenic to broccoli raab. In addition, broccoli raab strains were pathogenic to grasses but not tomato, which was a pattern unlike other pathovars

Table 3. Responses of broccoli raab, cauliflower, tomato, and various grasses when inoculated with broccoli raab strains and Pseudomonas syringae pvs. coronafaciens, maculicola, and tomato

\begin{tabular}{|c|c|c|c|c|c|c|c|c|c|c|c|c|}
\hline \multirow[b]{3}{*}{ Plant } & \multicolumn{12}{|c|}{$P$. syringae strain $^{y}$} \\
\hline & \multicolumn{4}{|c|}{ Broccoli raab } & \multirow{2}{*}{$\begin{array}{c}\text { pv. coron. } \\
\text { 0893-49 }\end{array}$} & \multicolumn{4}{|c|}{ pv. maculicola } & \multicolumn{3}{|c|}{ pv. tomato } \\
\hline & 1097-11 & 1097-12 & 1097-13 & $1097-14$ & & 0197-30 & 0694-18 & 0788-18 & 0197-29 & 0482-1 & 0183-4 & 0683-23 \\
\hline Broccoli raab & + & + & + & + & - & - & - & - & - & - & - & - \\
\hline Cauliflower & + & + & + & + & NT & + & + & + & + & - & - & - \\
\hline Tomato & - & - & - & - & - & + & - & + & - & + & + & + \\
\hline Calif. brome & + & + & + & + & NT & - & - & - & - & - & - & - \\
\hline Corn cv. KK $\mathrm{K}^{\mathrm{z}}$ & - & - & - & - & NT & - & - & - & - & - & - & - \\
\hline Corn cv. SQ & - & - & - & - & NT & - & - & - & - & - & - & - \\
\hline Oat & + & + & + & + & NT & - & - & - & - & - & - & - \\
\hline Rye & - & - & - & - & NT & - & - & - & - & - & - & - \\
\hline Timothy & + & + & + & + & NT & - & - & - & - & - & - & - \\
\hline Neg. contr. & - & - & - & - & - & - & - & - & - & - & - & - \\
\hline
\end{tabular}

$\mathrm{y}^{\mathrm{y}}=$ plants showed disease symptoms after inoculations, and bacteria similar to the original strains were isolated and characterized. $-=$ no disease symptoms developed after inoculations. NT = not tested.

${ }^{\mathrm{z}}$ Corn cultivars: KK = Kandy Korn, $\mathrm{SQ}=$ Silver Queen . 
tested. These observations suggest a need to differentiate the broccoli raab strains from other related pathovars in disease management, and we therefore propose that the broccoli raab strains be considered a new pathovar.

In the Salinas Valley, broccoli raab is planted in dense stands $(990,000$ seed per hectare on 4 to 6 seed lines per 1-m centerto-center beds) and is always irrigated by sprinklers. The resulting dense canopy and abundant moisture create ideal conditions for the development of this bacterial leaf spot disease, which at times results in significant losses of healthy leaves.

On the basis of our greenhouse inoculation experiments, this pathogen can infect many other crucifers grown in the Salinas Valley as well. While it is conceivable that alternate crucifer hosts might have impacts on the epidemiology of the disease on broccoli raab, field surveys indicated that severely infected broccoli raab fields were usually not in close proximity with other crucifer plantings. On the contrary, the development of severe disease in directseeded broccoli raab fields, and the apparent lack of alternate hosts in adjacent or nearby fields, strongly suggests that initial inoculum may be seedborne in broccoli raab. It is interesting to note that when cauliflower is inoculated with $P$. syringae pv. maculicola and $P$. syringae from broccoli raab, the symptoms caused by the two pathogens are indistinguishable from one another. Yet broccoli raab is evidently not a host to $P$. syringae pv. maculicola.

\section{ACKNOWLEDGMENTS}

We thank H. A. Agamalian, S. Atwood, R. Bunch, T. G. Gonzales, J. Manassero, E. Mora, E. D. Oakes, and A. Van Buren for their assistance. We thank Clyde Robin Seed Company and Leighton Seed Company for providing seed.

\section{LITERATURE CITED}

1. Bender, C. L., Stone, H. E., Sims, J. J., and Cooksey, D. A. 1987. Reduced pathogen fitness of Pseudomonas syringae pv. tomato Tn5 mutants defective in coronatine production. Physiol. Mol. Plant Pathol. 30:273-283.

2. Bender, C. L., Young, S. A., and Mitchell, R. E. 1991. Conservation of plasmid DNA sequences in coronatine-producing pathovars of Pseudomonas syringae. Appl. Environ. Microbiol. 57:993-999.

3. Cuppels, D., and Kelman, A. 1974. Evaluation of selective media for isolation of soft rot bacteria from soil and plant tissue. Phytopathology 64:468-475.

4. Denny, T. P. 1988. Phenotypic diversity of Pseudomonas syringae pv. tomato. J. Gen. Microbiol. 134:1949-1960.

5. Fanizza, G., Damato, G., and Bianco, V. V. 1992. A multivariate morphometric study on landrace differentiation in broccoli raab (Brassica rapa L.). Acta Hortic. 318:195-200.

6. Hendson, M., Hildebrand, D. C., and Schroth, M. N. 1992. Relatedness of Pseudomonas syringae pv. tomato, Pseudomonas syringae pv. maculicola, and Pseudomonas syringae pv. antirrhini. J. Appl. Bacteriol. 73:455-464.

7. Keane, P. J., Kerr, A., and New, P. B. 1970. Crown gall of stone fruit. II. Identification and nomenclature of Agrobacterium isolates. Aust. J. Biol. Sci. 23:585-595.

8. Klement, Z. 1963. Rapid detection of pathogenicity of phytopathogenic Pseudomonads. Nature (Lond.) 199:299-300.

9. Koike, S. T. 1997. Broccoli raab as a host of Alternaria brassicae in California. Plant Dis. 81:552.
10. Koike, S. T., and Saenz, G. S. 1997. First report of powdery mildew, caused by Erysiphe cruciferarum, on broccoli raab in California. Plant Dis. 81:1093.

11. Kovacs, N. 1956. Identification of Pseudomonas pyocyanea by the oxidase reaction. Nature (Lond.) 178:703.

12. Lelliott, R. A., Billing, E., and Hayward, A. C. 1966. A determinative scheme for the fluorescent plant pathogenic Pseudomonads. J. Appl. Bacteriol. 29:470-489.

13. Little, E. L. 1995. Etiology and epidemiology of celery bacterial blight in California, and molecular detection and characterization of three Pseudomonas syringae pathovars. Ph.D. thesis. University of California, Davis.

14. Palmer, D. A., and Bender, C. L. 1993. Effects of environmental and nutritional factors on production of the polyketide phytotoxin coronatine by Pseudomonas syringae pv. glycinea. Appl. Environ. Microbiol. 59:1619-1626.

15. Schaad, N. W., ed. 1988. Laboratory Guide for Identification of Plant Pathogenic Bacteria. American Phytopathological Society, St Paul, MN.

16. Stead, D. E. 1988. Identification of bacteria by computer-assisted fatty acid profiling. Acta Hortic. 225:39-46.

17. Takikawa, Y., Nishiyama, N., Ohba, K. Tsuyumu, S., and Goto, M. 1994. Synonymy of Pseudomonas syringae pv. maculicola and Pseudomonas syringae pv. tomato. Pages 199-204 in: Plant Pathogenic Bacteria. M. Lemattre, S. Freigoun, K. Rudolph, and J. G. Swings, eds. INRA, Orstom, Paris.

18. Thornley, M. J. 1960. The differentiation of Pseudomonas from other gram-negative bacteria on the basis of arginine metabolism. J. Appl. Bacteriol. 23:37-52.

19. Wiebe, W. L., and Campbell, R. N. 1993 Characterization of Pseudomonas syringae pv. maculicola and comparison with $P$. s. tomato. Plant Dis. 77:414-419. 